\title{
FAMILY ROLES AS FAMILY FUNCTIONING REGULATORS
}

\begin{abstract}
The author examines the problems related to the formation and functioning of family roles. Having social roots, family roles appear at the individual level by performing the social function of the family formation as a social institute.
\end{abstract}

Keywords: family, family role, family status, historical development of family.

Family statuses and roles appear as social mechanisms regulating the manifestations of a family-member. When referring to the theory of roles being applied in the field of family psychology, it should be noted that the family role in the modern psychology is defined as an entirety of social roles, which are performed by individuals as a consequence of the fact that they have families, whereby they occupy a certain position (positions). Moreover, as Sedrak Sedrakyan notes, a more specific study divides the roles into two groups: intra-family and inter-family roles (Sedrakyan 2010: 52-53). "Intra-family are considered to be those statuses and roles, - writes Sedrakyan, - which the familymembers assume and perform only when interacting with the members of that family. These are marital roles (female and male), parental roles (father and mother), and filial roles (son, daughter, sister, and brother)". The specified roles, according to Sedrakyan, are characteristic for nuclear families. In extended and archaic families, we may encounter some intra-family roles, such as grandfather and grandmother, aunt, uncle and other roles (Sedrakyan 2010: 53).

What functions are the family roles endowed with? Even during the times of formation of the theory of roles the role was considered as a unit of a social structure, as a behavior model having social conditionality. In the work called "Study of Man" Linton writes that availability of patterns of reciprocal behavior among individuals or groups of individuals constituting the society is required for social functioning.

Such patterns of behavior are called status. Moreover, Linton distinguishes dual application of the concept of status: the particular and the general. In the first case, when the concept of status is applied in its abstract sense, it is linked to the particular pattern, form of behavior. On the other hand, from its generalized aspect, an individual's status is considered as a sum of his/her specific statuses and expresses his/her position towards the society (Linton, 1936: 113).

In Linton's definition of the social status the following fact is more important to us that the status here is considered as an entirety of an individual's rights and obligations. And, as Linton observes, since these rights and obligations find their expression through the individual, it is quite difficult to differentiate the individual from his/her status. The status, according to Linton, is the entirety of potential opportunities of behavior and, depending on the individual, can be realized with certain efficiency, good or bad (Linton, 1936: 113).

The role, as Linton defined it, represents the dynamic aspect of the status. An individual occupies 
a certain social status and realizes it within the relationship with other statuses. When the individual exercises the rights and fulfils the obligations constituting his/her status, he/she performs a role that corresponds to that status. The roles and statuses constitute an entirety, and, as Linton notes, their separation carries only a purely academic significance: there are no roles without statuses, and there are no statuses without roles (Linton, 1936: 114).

As in the case of the status, Linton distinguishes two options for application of the concept of role. In one instance he speaks about particular roles. Each individual performs numerous roles, which stem from various social samples of behavior. In other instances all the roles performed by an individual are consolidated and generalized under the concept of role. In these circumstances the concept of role determines the individual's obligations in relation to the society and the individual's expectations from the society (Linton, 1936: 114).

As we can see the statuses and roles, having a social conditionality, however, are manifested through an individual only, are inseparable from an individual and perform the function of regulating the individual's behavior. Indeed, when analyzing Linton's theory, Sprot directly mentions that the role is the form of behavior that corresponds to a specific status. The status, in its turn, appears as a social position, around which the individual's behavior evolves (Sprot, 1952: 153).

It can be concluded from the above-said that a family-member's behavior is determined by the family roles performed by the individual. Meanwhile, regardless of the fact that family roles and statuses are realized at the individual level, their importance has an emphasized social nature: these generally serve the purpose of satisfying the social needs.

It is the latter aspect due to which the family is considered as a social institution. According to Druzhinin, the family is not only a social group, but a social institution, too. Druzhinin continues that "according to the definition of sociologists the entirety of social roles and statuses is called an "institution", the importance of which is satisfaction of a certain social need" (Druzhinin, 2002: 45). Moreover, if the family institution gets depreciated, it means that the household consanguineous groups do not perform the functions, which satisfy the corresponding social needs (Popenoe, 2002: 151).

It actually turns out that the status-and-role system of the family serves the purpose of family functioning. Each society "creates" such a system, which, being manifested at the individual level, serves the functioning of a social institution, such as the family, and determines its peculiarities.

In this regard, depending on the social order, the structure and functions of the family also change. According to Schneider, "It can be agreed that each culture gives birth to a certain normative model of the family, or to be more specific - a group of models. The structure of the normative model includes elements - the members of the family, each of which is characterized by a certain status, i.e. a position with certain rights and obligations, which is related to the corresponding form of behavior (Schneider, 2006: 39).

The influence of social and cultural environment on the role structure of the family is clearly manifested throughout historical development of the family. Thus, when observing the family from the perspective of historical development, Morgan distinguishes five main types of the family, each of which is characterized by a unique family structure and certain types of intra-family ties and relationships. These are:

1. The consanguine family - is formed within the same group as a result of consanguineous marriage of sisters and brothers, nephews and nieces.

2. The punaluan family - is formed as a result of marriage with sisters and nieces and the husbands of each of them, as well as brothers and nephews and the wives of each of them. In addition, it is not necessary that the husbands of the 
sisters in the first case and the wives of the brothers in the second case share blood proximity/ consanguineous ties. In all cases such families are group families: the group of men marries the group of women.

3. The syndyasmian/pairing family - is formed as a result of one couple's marriage, yet without the right for exclusive cohabitation. The marriage continues as long as it satisfies the couple.

4. Patriarchal family - is formed as a result of one man's marriage to several women, while women are isolated.

5. Monogamous family - is formed as a result of one couple's marriage with the right for exclusive cohabitation (Morgan 1907: 383-385).

As we can see, Morgan's classification of historical types of families is based on the structural peculiarities of the family. In some cases importance is attributed to the type of consanguineous ties of the spouses (sisters-brothers, nephewsnieces), in other cases importance is attributed to the number of parties engaged in marital relationships (group marriages in punaluan and patriarchal families, bigamies in bigamous and monogamous families), whereas in the third case importance is attributed to the factor of marital relationships (the right for exclusive cohabitation in the case of a monogamous family and its absence in a bigamous family).

Some historical forms of the family are excluded from Morgan's system. For example, in the work of the Danish philosopher, sociologist and educator Carl Nicolai Starcke called "The Primitive Family in its Origin and Development" (Starcke, 1889: 141158) we encounter the description of polyandrous and levirate marriages. In a sense the polyandry is contrasted with the patriarchy: in this case within the same period of time a woman may be in marital relationships with several men. In the case of a levirate marriage a man is obliged to marry the wife of his deceased brother, while a woman is obliged to marry the brother of her deceased husband. And if in the first case the matter refers to the quantita- tive aspect of marital relationships (polygamy), then in the second case importance is attributed to the nature of consanguineous ties within the marrying couple (the sister-in-law and the brother-in-law).

For the sake of discussing the status-and-role system of the family, importance is also attributed to the issue of historical modification of marital relationships. The social order determines not only the nature of the family, but the form of marital relationships as well. The latter has a historical conditionality. Thus, when speaking about historical development of marital relationships, Zatsepin notes that the marital form of regulating the relationships among the individuals belonging to different sex groups has not immediately emerged. According to Zatsepin, marriage is a form of relationship between a man and a woman, which is historically conditioned and certified and regulated by the society, which defines their rights and obligations to one another, as well as their common children. Marriage is a traditional form of formation of the family and its public control, one of the means of the society's self-preservation and development (Zatsepin, 2002: 4).

As we can see, the studies of historical development of the family and marital relationships reveal, and in some cases they are even based on the provision of the social conditionality of the family and marital relationships. This provision is also fundamental for the comparative study of the families functioning within the same period of time in different social and cultural environments. For example, in the work dedicated to marital relationships in China we encounter some paragraphs of the marriage law on relations such as bigamy, marriages settled by families, marriages by convenience, and paragraphs prohibiting blood/consanguineous marriages (Domenach, 1991: 17).

Unlike China, some African countries adopted the practice of marriages settled by families. Here, from the perspective of the traditional law, the marriage agreement between the large family groups serves as foundation for the marriage. 
Moreover, the relationships of the wife and the husband - the immediate parties to the settlement - are derived from the settlement between the families (Sinitsina, 1989: 41). The same is true for polygamy, particularly for polygyny (multiple wives), which is traditionally considered to be a form of marriage for some African nations and stems from their everyday life and conditions of life activity (Sinitsina, 1989: 46).

The influence of the social existence on the family and marriage relationships is obvious. The social order is determined by numerous factors (environmental and climate, political, economic, and living conditions), which directly or indirectly determine the nature of the family and marriage, too. According to Kislyakov, "The level of development of the farming agriculture or animal husbandry, crafts, trade relations, monetary economy, and political life has also left its influence on some institu-

\section{REFERENCES}

Sedrakyan, S. (2010). Y'ntaniqi hogebanut'yun (psycology of family), Yerevan, "Urartu" hamalsaran

Domenazh, Zh., Shanmin, Kh. (1991). Semeinye otnosheniya $v$ Kitae (Family Relationships in China), Moscow, Nauka, Glavnaya redaktsiya vostochnoi literatury.

Druzhinin, V. (2002). Psikhologiya sem'i. Khrestomatiya, pp. 60-77, Samara, Izdatel'skii Dom Bakhrakh.

Zatsepin, V. (2002). Psikhologiya sem'i. Khrestomatiya, pp. 4-31, Samara, Izdatel'skii Dom Bakhrakh.

Kislyakov, N. (1969). Ocherki po istorii sem'i i braka u narodov Srednei Azii i Kazakhstana, (Essays on the History of the Family and Marriage among the Peoples of Central Asia and Kazakhstan), Leningrad, Nauka. tions, such as the family and marriage" (Kislyakov, 1969: 12).

As we can see, depending on the ethno cultural, social and economic conditions, different nations may have different perceptions about the family and marriage, as well as about their structural characteristics. Moreover, the social order directly influences the forms of family and marriage by determining their nature or by means of legal acts or traditional norms historically established within the given society.

Thus, it can be said that the status-and-role structure of the family contributes to the functioning of the family by bringing into compliance as much as possible at the individual and social levels. The family performs the role of a mediator between the individual and the society by regulating their relationships.

Popenoe, D. (2002). Psikhologiya sem'i. Khrestomatiya, pp. 150-161, Samara, Izdatel'skii Dom Bakhrakh.

Sinitsyna, I. (1989). Chelovek i sem'ya v Afrike. (The Man and the Family in Africa), Moscow, Nauka, Glavnaya redaktsiya vostochnoi literatury.

Shneider, L. (2006). Semeinaya psikhologiya (Family Psychology), Moscow, Akademicheskii Proekt, Ekaterinburg, Delovaya kniga.

Linton, R. (1936). The Study of Man. An Introduction. New York, Appleton-CenturyCrofts, INC.

Morgan, L. (1907). Ancient Society, or Researches in the Lines of Human Progress from Savagery through Barbarism to Civilization. New York, Henry Holt and Company.

Sprot, W. (1952). Social Psychology. London, Methuen and Co.LTD.

Starcke, N. (1889). The Primitive Family in its Origin and Development. London. Kegan Paul, Trench \& Co. 